\title{
Correction to: Length of cultivation determines native and non-native weed richness in crop fields worldwide
}

\author{
Makihiko Ikegami $(\mathbb{D} \cdot$ Elizabeth Wandrag • Richard P. Duncan • \\ Philip E. Hulme
}

Published online: 24 September 2021

(C) Springer Nature Switzerland AG 2021

\section{Correction to: Biol Invasions (2019) 21:363-375 https://doi.org/10.1007/s10530-018-1828-7}

The wrong Supplementary file was originally published with this article; it has now been replaced with the correct file.

Supplementary Information The online version contains supplementary material available at https://doi.org/10.1007/ s10530-021-02632-2.

The original article can be found online at https://doi.org/10. 1007/s10530-018-1828-7.

M. Ikegami - E. Wandrag - R. P. Duncan - P. E. Hulme Bio-Protection Centre, Lincoln University, Lincoln, Christchurch 7647, New Zealand e-mail: Lizzie.Wandrag@canberra.edu.au

R. P. Duncan

e-mail: richard.duncan@canberra.edu.au

P. E. Hulme

e-mail: Philip.Hulme@lincoln.ac.nz

M. Ikegami $(\bowtie)$

National Institute for Environmental Studies, Tsukuba, Japan

e-mail: Makihiko.ikegami@gmail.com
The original article has been corrected.

Publisher's Note Springer Nature remains neutral with regard to jurisdictional claims in published maps and institutional affiliations.

E. Wandrag · R. P. Duncan

Institute for Applied Ecology, University of Canberra, Bruce, ACT 2617, Australia 